\title{
Bioindicators of pollutant exposure in the northwestern Mediterranean Sea
}

\author{
T. Burgeot ${ }^{1, *}$, G. Bocquéné ${ }^{1}$, C. Porte ${ }^{3}$, J. Dimeet ${ }^{2}$, R. M. Santella ${ }^{4}$, \\ L. M. Garcia de la Parra ${ }^{3}$, A. Pfhol-Leszkowicz ${ }^{5}$, C. Raoux ${ }^{3}$, F. Galgani ${ }^{1}$ \\ ${ }^{1}$ IFREMER, Laboratoire d'écotoxicologie, BP 1049, F-44037 Nantes, France \\ ${ }^{2}$ IFREMER, Laboratoire environnement littoral, BP 330, F-83507 La Seyne-sur-mer, France \\ ${ }^{3}$ CSIC, Dept. de quimica ambiental, Jordi Girona 18-26, E-08034 Barcelona, Spain \\ ${ }^{4}$ Columbia University, 701 West 168th Street, New York, New York 10032, USA \\ ${ }^{5}$ ENSAT, 145 Avenue Muret, F-30176 Toulouse, France
}

\begin{abstract}
Several bioindicators were used to evaluate the biological and genotoxic effects of marine pollutants near large coastal cities in the northwestern part of the Mediterranean Sea. Three target species of teleosts were selected: red mullet Mullus barbatus and 2 types of comber (Serranus hepatus and $S$. cabrilla). Induction of ethoxyresorufin-O-deethylase (EROD) activity specific for polycyclic aromatic hydrocarbons (PAH) and polychlorinated biphenyls (PCB) was measured in the livers of the fish, and inhibition of acetylcholinesterase (AChE) by organophosphorus insecticides and carbamates was measured in their muscle tissues. Maximal EROD activities (16.8 \pm 2.7 to $19.4 \pm 4.2 \mathrm{pmol} \mathrm{min}^{-1} \mathrm{mg}$ protein ${ }^{-1}$ ) recorded in red mullet near Barcelona (Spain), Milazzo (Sicily) and Ostia (Italy) indicated exposure to high pollutant concentrations. Inhibitions of $\mathrm{AChE}$ activity were low in areas remote from agricultural and industrial activity. The highest inhibitions were measured at sites of heavy industrial and domestic waste, such as Genoa and Naples (ltaly), Rio Ter (Spaın), Barcelona, and Cortiou (France). Inhibition of AChE activity was higher at a given station for younger individuals 120 to $140 \mathrm{~mm}$ in length than for those 160 to $180 \mathrm{~mm}$ long. Antioxidant enzyme activities (catalase, superoxide dismutase, glutathione peroxidase and DT-diaphorase) were measured in red mullet livers at 5 stations along the French and Spanish coasts. Catalase activity was highest at Cortiou, consistent with higher levels of pollution, and lower at Mallorca (Balearic Islands). Varying responses were obtained for the other antioxidant enzymes. Glutathione S-transferase (GST), a detoxufication enzyme, was also measured in the livers of red mullet fish and found to be significantly higher at Cortiou than at the other locations studied. Chemical measurement of PAH in surface sediment indicated the pyrolytic origin of this contaminant for all stations except Milazzo (petroleum origin). Detection of DNA adducts as a bioindicator of exposure to carcinogenic substances was tested according to 2 complementary assay techniques: enzymelinked immunosorbent assay (ELISA) and ${ }^{32}$ P-postlabeling. ELISA revealed maximal quantities of PAHDNA at Barcelona (15 adducts per $10^{8}$ nucleotides), Cap Finale (Corsica) (20.8) and Milazzo (15.5). The richest adduct profiles were detected by the ${ }^{32} \mathrm{P}$ method at Antibes (France), Santa Ponza (Balearic Islands), Milazzo and Cap Finale, with a maximum of 6.2 adducts per $10^{8}$ nucleotides at Milazzo. This multımarker approach showed that pollutant exposure levels vared according to site. With a sedimentary PAH profile apparently resulting from petroleum pollution, the Milazzo station had the greatest quantity of DNA adducts and the highest inductions of EROD activity and AChE inhibitions in $M$. barbatus and S. hepatus.
\end{abstract}

KEY WORDS: EROD - GST - AChE - Antioxidant enzymes - Biomonitoring - DNA adducts PAH Mullus barbatus

\section{INTRODUCTION}

Evaluation of the impact of contaminants in coastal areas of the Mediterranean Sea has become a priority for the countries directly concerned. With the support

-E-mail: tburgeot(aifremer.fr of international organizations (e.g. FAO: Food and Agriculture Organization of the United Nations; UNEP: United Nations Environment Programme; IOC: Intergovernmental Oceanographic Commission) for the coordination of environmental protection, a pilot program for biomonitoring in the northwest Mediterranean (MED-POL) was set up to develop sensitive and 
reliable methods for estimating the state of exposure of organisms to pollutants. Studies of the activity of bioprotection systems in representative marine organisms of coastal benthic ecosystems were performed (GICBEM 1992) along French coasts, and monitoring of biological effects at the Marseille/Fos-sur-Mer pilot site was set up in 1992 in the context of the National Observation Network (NON) (Burgeot et al. 1994a). A biomonitoring program was initiated in the Provence/ Alpes/Cote d'Azur region in the northwestern part of the Mediterranean to develop and validate 4 biomonitoring techniques selected in the context of MED-POL, the Mediterranean pollution network (Roméo et al. 1993)

The purpose of the present study was to test the bioindicators recommended by the International Council for the Exploration of the Sea (ICES) and MED-POL for monitoring the marine environment at sites particularly exposed to domestic and industrial waste. Biochemical indicators were measured, along with chemical and genotoxic parameters, in 3 target species of teleosts, red mullet (Mullus barbatus) and 2 combers (Serranus hepatus and $S$. cabrilla), in coastal areas of the northwest Mediterranean adjacent to large cities. Measurements of hepatic monooxygenase activities and neurospecific activity are now recognized and used as bioindicators of exposure to chemical contaminants (ICES 1994). Ethoxyresorufin-Odeethylase (EROD), specific for polycyclic aromatic hydrocarbons (PAH) and planar polychlorinated biphenyls (PCB), and glutathione S-transferase (GST, EC 2.5.1.18), a detoxification enzyme (Phase II), were measured in the fish livers. Acetylcholinesterase (AChE), specifically inhibited by organophosphorus insecticides and carbamates, was measured in muscle tissues of the 3 target species. The activity of antioxidant hepatic enzymes such as catalase, superoxide dismutase (SOD, EC 1.15.1.1), glutathione peroxidase selenium (GPX, EC 1.11.1.9) and DT-diaphorase (NAD)(P)H-quinone oxidoreductases (NADPH, EC 1.6.99.2) were measured as potential biomarkers of oxidative stress (Di Guilio et al. 1989). Increase in activities of antioxidant enzymes following field (Livingstone et al. 1992) and experimental exposure to xenobiotics (Mather-Mihaich \& Di Guilio 1986, 1991 a, Markovics et al. 1987) have been detected in a number of fish species, but the responses have not been quantitatively reproducible. The use of these enzymes as biomarkers for environmental oxidative stress is therefore unproven, but merits further research.

The use of xenobiotic DNA adducts as indicators of exposure to genotoxic compounds is a more recent procedure recommended for environmental studies (McCarthy et al. 1989, Varanasi et al. 1989, Stein et al. 1992). In some fish species, the amount of an adduct formed in a target tissue is modulated by Phase II enzymatic reactions, while in other species, the extent of activation of the carcinogen by Phase I enzymes is the major determinant in adduct formation. As a measure of exposure, DNA adducts integrate the factors of uptake, metabolism, and repair and provide an assessment of the dose of carcinogen reaching a target tissue such as liver (Maccubin 1994). In 1964, Dawe et al. suggested the use of bottom-feeding fish to detect environmental carcinogens. We chose to measure DNA adducts in the liver of Mullus barbatus because this fish is uniformly distributed along the coasts of the northwestern Mediterranean Sea and because it lives in contact with the sediment. The most widely used method for DNA adducts assessment is the use of radiolabeled chemicals ( ${ }^{32} \mathrm{P}$-postlabeling) (Baird 1979). This technique has proven valuable for the chemicals that can be synthesized in radioactive forms with high specific activities (Maccubin 1994). Therefore, an alternative method, such as an immunochemical one, that does not require administration of radiolabeled compounds, is needed. We chose ${ }^{32} \mathrm{P}$-postlabeling and immunochemical (ELISA) methods based on studies of biomonitoring application in the marine environment (Stein et al. 1993, Ericson et al. 1995) and in humans (Schoket et al. 1993). All of these sensitive methods have advantages and disadvantages. The method chosen for adduct analysis depends on the types of adducts to be detected, the availability of antibodies and the instrumentation that might be especially required for monitoring applications. ${ }^{32} \mathrm{P}$-postlabeling is a very sensitive but very complex method. Immunochemical detection of BaP DNA adducts is simpler for a routine application; the major adduct formed in vivo is the BaP DNA adduct (BPDE) (Sikka et al. 1991)

As the sediment is a possible source of genotoxic chemicals, analyses of PAH in sediment and measurements of DNA adducts (ELISA and ${ }^{32} \mathrm{P}$-postlabeling) in red mullet livers were performed in the present study to identify the origin of pollution and demonstrate genotoxic alterations of DNA. This study presents the first results obtained on a large geographical scale for the northwestern Mediterranean Sea, enabling biomonitoring of contaminant effects in sensitive areas.

\section{MATERIALS AND METHODS}

\section{Fish and sediment}

Our cruise followed a route in the form of a loop, from 30 March to 28 April 1994 We first sailed from France toward Spain along the coast, following the dominant northeast current which conveys pollutants toward the southwest. We then passed through the 
Balearic Islands of Spain, reached the Sicilian coast, and sailed northward in the Tyrrhenian Sea of Italy, following the Liguro-Provençal current which skirts the continental slope from the Gulf of Genoa to the Catalan Sea (see Fig. 1).

Mullus barbatus, Serranus cabrilla and $S$. hepatus were trawl-fished on the continental shelf to obtain 8 individuals of each species per station. The trawling runs were conducted for 20 min periods. When trawling was impossible, combers were fished with a rod and line. As the cruise covered a considerable geographical area, we were obliged to concentrate our fishing efforts on trawling operations; this explains why sampling was better for the red mullet, which is easier to obtain by this technique. The combers were thus considered as complementary target species.

Individuals of the same size class, without sexual differentiation, were selected to ensure uniform sampling. Mean sizes (in mm) were $129 \pm 14.1$ to $160 \pm 7$ for Mullus barbatus, $90 \pm 12$ to $99 \pm 14$ for Serranus hepatus and $131 \pm 28$ to $186 \pm 28$ for $S$. cabrilla. Liver and muscle tissues were collected, washed in buffer $(\mathrm{KCl}$ $150 \mathrm{mM}$, Tris $50 \mathrm{mM}, \mathrm{pH} 7.4$ ) and stored in liquid nitrogen for biochemical analysis. Nineteen stations were sampled in coastal areas near large northwest Mediterranean cities

Surface sediment collected with a scoop before each trawling run was stored at $-20^{\circ} \mathrm{C}$ for chemical analysis.

\section{Biochemical analyses}

EROD measurement. EROD activity was assayed in fish livers using a fluorometric microplate reader, according to the method of Galgani \& Payne (1991).

For extract preparation, liver tissue was washed in buffer (Tris $50 \mathrm{mM}, \mathrm{KCl} 150 \mathrm{mM}, \mathrm{pH} \mathrm{7.4)}$ ) at $4^{\circ} \mathrm{C}$ and then ground for $10 \mathrm{~s}$ in an Elvehjem potter before centrifugation $\left(9000 \times g\right.$ for $15 \mathrm{~min}$ at $4^{\circ} \mathrm{C}$ ). The supernatant was used as an enzymatic solution.

Proteins were measured in supernatant according to the method of Bradford (1976), using BSA as the standard protein. Measurements were performed by microplate spectrophotometer readings at $595 \mathrm{~nm}$, and concentrations were expressed in $\mathrm{mg} \mathrm{ml}^{-1}$.

Analysis of EROD activity was performed at $4^{\circ} \mathrm{C}$ using $10 \mu \mathrm{l}$ of extract in $200 \mu \mathrm{l}$ of buffer (Tris $0.1 \mathrm{M}$, $\mathrm{NaCl} 0.1 \mathrm{M}, \mathrm{pH} 8.0$ ) containing $2 \mu \mathrm{M}$ of 7 -ethoxyresorufin $(10 \mu \mathrm{l})$ and $0.25 \mathrm{mM}$ of NADPH $(10 \mu \mathrm{l})$. Activity was determined by kinetic measurement at room temperature in supernatant. The quantity of resorufin formed by catalysis was measured by fluorometry (Galgani \& Bocquéné 1989) according to the modified method of Burke \& Mayer (1974), with excitation at
$544 \mathrm{~nm}$ and emission at $584 \mathrm{~nm}$. Kinetics were determined in supernatant at the final $1 \%$ dilution. Microplate measurements were performed using a Fluoroscan II fluorometric reader (Grzebyk \& Galgani 1991), each plate being read in 1 min. Kinetics were linear for 10 min. An external resorufin standard was used to convert fluorescence units into pmol. Results are expressed in pmol $\mathrm{min}^{-1} \mathrm{mg}$ protein ${ }^{-1}$.

GST measurement. Glutathione S-transferase (GST) activity was measured in the cytolic fraction using 1 chloro-2,4-dinitrobenzene (CDNB) as a substrate, as described by Habig et al. (1974), the final reaction mixture containing $1 \mathrm{mM} C D N B$ and $1 \mathrm{mM}$ reduced glutathione.

AChE measurement. AChE was measured according to the colorimetric method of Ellman et al. (1961) as adapted to a microplate reader. The staining produced by interaction of the DTNB (dithio-bis-nitrobenzoic acid) ion with free thiol groups was measured at $412 \mathrm{~nm}$ during acetylthiocholine hydrolysis by AChE.

Muscle tissue from 8 individuals per species obtained at each sampling site was removed and immediately stored in liquid nitrogen. Depending on conditions of local availability, samples of the 3 species were collected as follows: Mullus barbatus, 14 stations; Serranus cabrilla, 8 stations; and S. hepatus, 5 stations.

Specific antioxidant enzymes. Supernatant after $10000 \times g$ centrifugation and cytosolic fraction $(100000 \times$ $g$ supernatant) were prepared essentially as described in Förlin \& Andersson (1985). The tissue was homogenized in a 1:4 tissue weight:buffer volume ratio in $100 \mathrm{mM}$ $\mathrm{KH}_{2} \mathrm{PO}_{4} / \mathrm{K}_{2} \mathrm{HPO}_{4}$, pH 7.4, containing $0.15 \mathrm{M} \mathrm{KCl}$.

Biochemical measurements were carried out on a UVIKON 941 plus dual-beam spectrophotometer. Antioxidant enzymes were measured essentially as described in Livingstone et al. (1990). Catalase activity was measured in the cytosolic fraction $(100000 \times \mathrm{g}$ supernatant) using $50 \mathrm{mM} \mathrm{H}_{2} \mathrm{O}_{2}$ as a substrate. SOD activity was determined by the degree of inhibition of the cytochrome $c$ reduction by superoxide anion radical as described in McCord \& Fridovich (1969). The activity of this enzyme is given in SOD units (1 unit = $50 \%$ of the inhibition of the cytochrome $c$ reduction). GPX activity was measured by the NADPH consumption during the formation of reduced glutathione by commercial glutathione reductase using $0.8 \mathrm{mM} \mathrm{H}_{2} \mathrm{O}_{2}$ as a substrate (Greenwald 1985). DT-diaphorase activity was measured in $10000 \times g$ supernatant as the dicumarol inhibitable part of NAD(P)H-dichlorophenol (DCPIP) reductase activity. The reduction of DCPIP was measured in the absence and presence of $100 \mu \mathrm{M}$ dicumarol as described by Benson et al. (1980). Cytosolic and $10000 \times g$ supernatant proteins were measured according to the method of Lowry et al. (1951). 


\section{Chemical analyses}

Chemical measurement of PAHs in sediment. Extraction and isolation of PAHs: Lyophilization was performed directly for $48 \mathrm{~h}$ (Telstar apparatus) in the containers used for total surface sediments and without preliminary freezing From 8 to $15 \mathrm{~g}$ of bulk sediment was extracted by sonification with a dichloromethane (DCM) methanol mixture $(2: 1 \mathrm{v} / \mathrm{v})$. The samples were first Vortex agitated into $75 \mathrm{ml}$ glass centrifuge tubes, with $50 \mathrm{ml}$ of solvent, then sonicated for $10 \mathrm{~min}$ and finally centrifuged at $5000 \mathrm{rpm}$ for $15 \mathrm{~min}$ (Beckman Model TJ-6 centrifuge); this was all performed 3 times.

Total organic extracts (TOE) were rotary evaporated under reduced pressure nearly to dryness then dried under a gentle stream of nitrogen. TOE purification was performed using $6 \mathrm{ml}$ microcolumn packed with $1 \mathrm{~g}$ of florisil (waters Sep-pack) previously conditioned with $40 \mathrm{ml} \mathrm{MeOH}$, then $20 \mathrm{ml}$ hexane. The PAH containing fraction was eluted by $20 \mathrm{ml}$ of hexane-DCM $(1: 1 \mathrm{v} / \mathrm{v})$ that was concentrated to about $1 \mathrm{ml}$ as described above. After transferring the mixture into a $1.5 \mathrm{ml}$ pelleter and drying it under a nitrogen stream, the PAH fraction was finally rediluted with a solution in iso-octane of Pyrene d10 (CIL, Woburn, MA, USA) used as an internal standard. All solvents (Merck, Darmstadt, Germany) were for organic trace analysis.

GC-MS analysis of PAHs: The PAH fractions were analysed in a GC 8000 series gas chromatograph coupled with an MD 800 series quadrupole mass spectrometer (Fison Instruments, Milan, Italy). Ion source and interface temperatures were held at 200 and $280^{\circ} \mathrm{C}$ respectively, and helium was used as carrier gas at $30 \mathrm{~cm}$ $\mathrm{s}^{-1}$. Injection was performed in the spitless mode, and a $25 \mathrm{~m}$ long fused silica column (0.2 mm i.d.) coated with a $0.25 \mu \mathrm{m}$ thick film of $5 \%$ diphenyl methylpolysiloxane (DB5) was used with the following temperature programme: $1 \mathrm{~min}$ at $90^{\circ} \mathrm{C}$, from 90 to $150^{\circ} \mathrm{C}$ at $15^{\circ} \mathrm{C} \mathrm{min}{ }^{-1}$ then from 150 to $310^{\circ} \mathrm{C}$ at $6^{\circ} \mathrm{C} \mathrm{min}^{-1}$. The electron energy was $70 \mathrm{eV}$ and single ion monitoring (SIM) was set as the detection mode with the following molecular ions as diagnostic: $m / z=178,184,192,198,202,206,212,228$, $252,276,278$ (dwell time $70 \mathrm{~ms}$ ) Peak integration was performed using the VG-Lab-Base software (Fison Instruments). The list of PAHs that were systematically analysed is indicated in Table 2. A standard mixture containing the 16 EPA (US Environmental Protection Agency) priority pollutant PAHs was used for identification and quantification of PAHs.

\section{Determination of PAH-DNA adducts}

Immunochemical method. Isolation of DNA: For DNA isolation, a $10 \%$ homogenate was prepared in
Tris $10 \mathrm{mM}$, pH 7.9, EDTA $1 \mathrm{mM}$ and $\mathrm{NaCl} 0.4 \mathrm{M}$, with sodium dodecyl sulfate added to give a final concentration of $0.2 \%$. Samples were treated with proteinase $\mathrm{K}$ (final concentration $200 \mu \mathrm{g} \mathrm{ml}^{-1}$ ) at $37^{\circ} \mathrm{C}$ for 1 to $2 \mathrm{~h}$, then extracted with phenol. The nucleic acids were collected by ethanol precipitation and resuspended in buffer Hog pancreas alpha-amylase was added to a final concentration of $200 \mu \mathrm{g} \mathrm{ml^{-1 }}$ and samples incubated at $37^{\circ} \mathrm{C}$ for $1 \mathrm{~h}$. After adjustment to $0.4 \mathrm{M} \mathrm{NaCL}$, RNase was added to a final concentration of $50 \mu \mathrm{g} \mathrm{ml}^{-1}$ and samples were incubated for $45 \mathrm{~min}$. Proteinase $\mathrm{K}$ was added to a final concentration of $100 \mu \mathrm{g} \mathrm{ml}^{-1}$ and incubation continued at $37^{\circ} \mathrm{C}$ for $45 \mathrm{~min}$. Samples were extracted with chloroform: isoamyl alcohol, DNA precipitated with ethanol and resuspended in PBS (phosphate buffered saline).

Determination of PAH-DNA adducts by ELISA: PAH diol-epoxide-DNA adducts were analysed by competitive ELISA essentially as previously described (Santella et aI. 1992). Briefly, 96-microwell black plates (Microfluor 'B', Dynatech Laboratories, Chantilly, VA, USA) were coated with $0.2 \mathrm{ng}$ BPDE-I-DNA (5 adducts per $10^{3}$ nucleotides). A previously characterized rabbit antiserum (Poirier et al. 1980) was used at 1:1600000 dilution and a standard curve was constructed by mixing $50 \mu$ liluted antiserum with BPDE-I-DNA (1.5 adducts per $10^{6}$ nucleotides) in carrier nonmodified calf thymus DNA (such that $50 \mu$ l contained 5 to 150 fmol BPFE-I-deoxyguanosine adduct in $50 \mu \mathrm{g}$ DNA) Test samples were assayed at $50 \mu \mathrm{g}$ well ${ }^{-1}$ after sonication and denaturation by boiling for $3 \mathrm{~min}$ and cooling on ice. Goat anti-rabbit IgG-alkaline phosphatase (Boehringer Mannheim, Indianapolis, IN, USA) was used at 1:400 dilution and the substrate was 4 -methylumbelliferyl phosphate $(100 \mu \mathrm{l}, 50 \mu \mathrm{g} \mathrm{ml}$ $0.1 \mathrm{M}$ diethanolamine $\mathrm{pH}$ 9.6). Fluorescence was read on a Microfluor reader (Dynatech Laboratories) connected to an IBM computer for data analysis. Samples were run in triplicate and median values used for determination of \% inhibition. For analytical purposes, those samples with $<15 \%$ inhibition were considered nondetectable and assigned a value of $1 / 10^{8}$, an amount midway between the lowest positive value and zero. A positive control of DNA isolated from animals treated with BaP and negative control of human fetal lung DNA was run with every assay.

Results are expressed as BPDE-I-DNA equivalent adducts but correspond to the quantification of multiple PAH diol-epoxide-DNA.

${ }^{32}$ p-postlabeling method: DNA was extracted and purified according to the method described by Reddy \& Randerath (1986) and modified by Pfhol-Leszkowicz et al. $(1991,1993)$. Labeled normal nucleotides and residual ATP were eliminated by an initial chromatography on polyethyleneimine-cellulose plate in solvent $\mathrm{NaH}_{2} \mathrm{PO}_{4}$ 
$2.3 \mathrm{M}, \mathrm{pH} 5.7$ overnight. The area deposit containing marked and purified adducts was cut and transferred onto another migration polyethylenimine-cellulose plate, in the solvent: urea $7.65 \mathrm{M}$ format $\mathrm{Li} 4.77 \mathrm{M}$, pH 3.5. Two migrations in solvent $\mathrm{NaH}_{2} \mathrm{PO}_{4} 0.6 \mathrm{M}$ and urea $5.95 \mathrm{M}, \mathrm{pH} 6.4$ and $\mathrm{NaH}_{2} \mathrm{PO}_{4} 1.7 \mathrm{M}, \mathrm{pH} 6$ were conducted perpendicularly to urea $7.65 \mathrm{M}$ format Li $4.77 \mathrm{M}$. pH 3.5 to attain a better adduct separation.

\section{Statistics}

Means \pm standard deviations (SD) for EROD activities were calculated from 4 replicates each for 8 fish per station. For $\mathrm{AChE}$, muscle tissue was treated individually and the values given in means \pm SD calculated for 8 individuals per station. Measurement of antioxidant enzymes was performed on 6 fish livers and the mean \pm SD calculated.

The smallest significant difference test (Z-test) was performed by comparing the station with the lowest induction (the reference station) with the other stations for EROD and stress proteins. For AChE activity, the lowest inhibition was compared with those of the other stations.
Mean DNA adduct measurements by ELISA were calculated from duplicates of a mixture of fish livers from the same station. The method of detecting adducts by ${ }^{32} \mathrm{P}$-postlabeling as well as the quantification of sediment PAH were qualitative and thus not suitable for statistical analysis.

\section{RESULTS}

\section{Measurement of EROD activity}

EROD activity was detected in 8 Mullus barbatus, Serranus cabrilla and $S$. hepatus livers (Burgeot 1994). The red mullet was considered the main target species because of better sampling (14 stations); the 2 combers were used as complementary species (11 stations). Measurement of EROD activity specifically induced by planar PCB and PAH allowed observation of maximal responses for red mullet at the Barcelona (Spain), Milazzo (Sicily) and Ostia (Italy) sites. For the combers, the 3 highest inductions of EROD activity were measured at Milazzo and Civitavecchia (Italy), Cortiou (France) and Santa Manza (France) (Fig. 1)

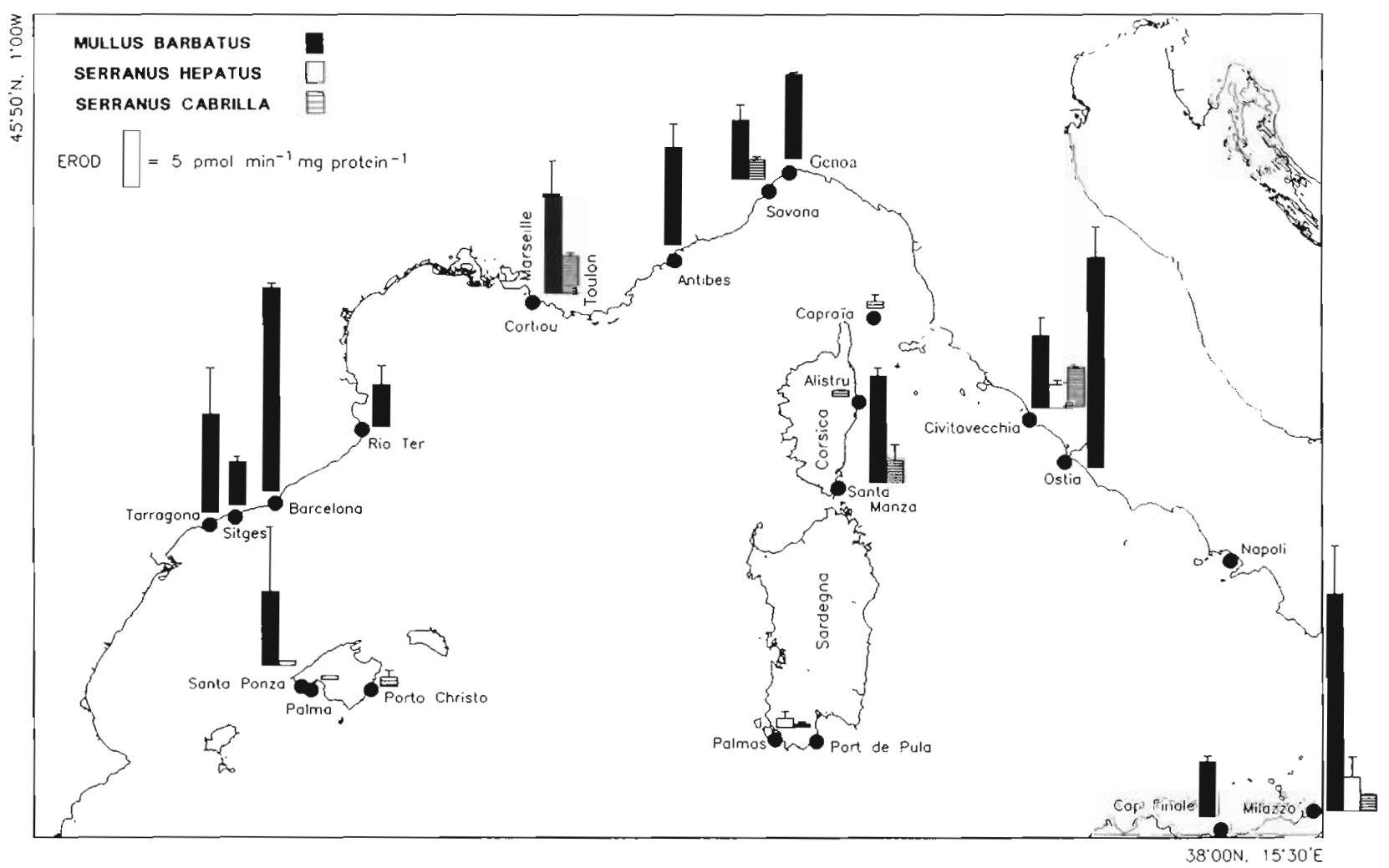

Fig. 1. Mullus barbatus, Serranus hepatus, S. cabrilla. Measurement of EROD activity in the livers of 3 target species of teleosts. Mean and SD, calculated from 4 replicates per individual, are shown for each station 

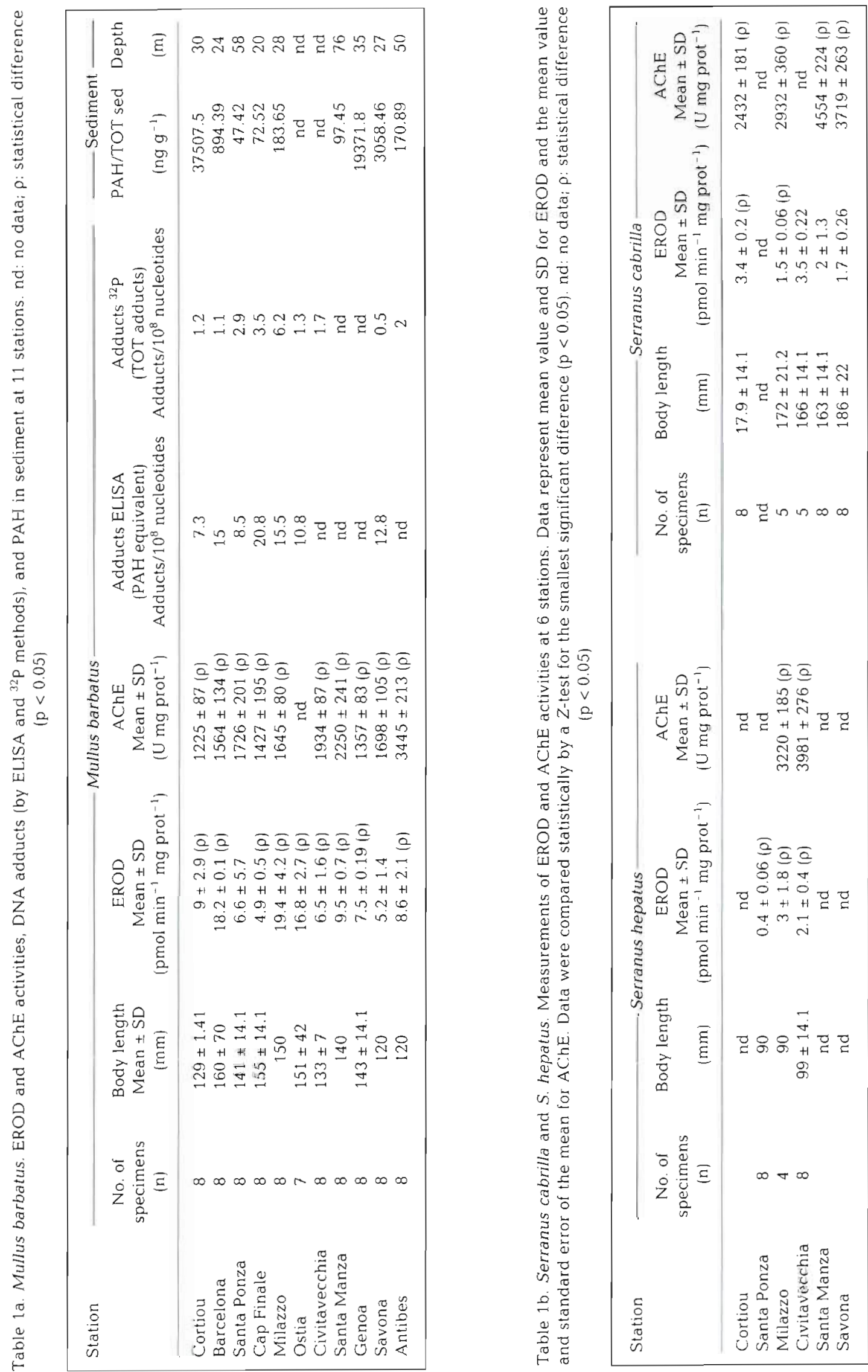
It was possible to compare the responses of at least 2 different species at 6 stations (Table 1). Milazzo was thus characterized by the highest inductions and Santa Ponza (Balearic Islands) by low inductions for Mullus barbatus and Serranus cabrilla. The Milazzo site was located next to an oil refinery, the likely source of complex mixtures of specific hydrocarbons. Santa Ponza, situated farther away from urban areas, was characterized by lower inductions of EROD activity.

High inductions were recorded at Civitavecchia for the combers, but at that site the red mullet showed a different sensitivity. Induction for red mullet at Civitavecchia was lower than the highest levels obtained at Ostia and Milazzo (Fig 1). The highest inductions of EROD activity for the combers were always much lower than those for red mullet (Narbonne et al. 1991).

Only 2 stations, Civitavecchia and Milazzo, allowed comparison of the response of all 3 species sampled (Table 1). The Milazzo station was characterized by high inductions for Mullus barbatus and Serranus hepatus (Fig. 1).

The Cortiou area, situated at a pilot site for the monitoring of biological effects along French coasts (Bur- geot et al. 1994a), showed high exposure to pollutants, with induction of EROD activity comparable to that of Civitavecchia (Table 1). Measurements of EROD activity recorded at Cortiou in the monitoring context showed that red mullet and comber were exposed to pollution originating from domestic sewage from the city of Marseille, France (Burgeot et al. 1994a, b). The results for EROD activity at Cortiou $\left(9 \pm 2.9 \mathrm{pmol} \mathrm{min}{ }^{-1}\right.$ mg protein $\left.{ }^{-1}\right)$ were significantly higher $(\mathrm{p}=0.004)$ than those at Rio Ter and Sitges (Spain) $(3.7 \pm 1.7$ and $3.9 \pm 0.5 \mathrm{pmol}^{\mathrm{min}}{ }^{-1} \mathrm{mg}$ protein ${ }^{-1}$ respectively) but only half as high as those for Milazzo, Ostia and Barcelona (Table 1). However, the Santa Manza station, despite its location remote from industrial and domestic sources of waste, had an EROD induction activity for red mullet comparable to that of Cortiou. At the Santa Manza station, high induction levels were also noted in October 1991 for Mullus barbatus and Serranus cabrilla, but no explanation was found for these high values (Burgeot et al. 1994b).

Comparisons among the different stations showed that observations for the target species did not correlate at the different sites.

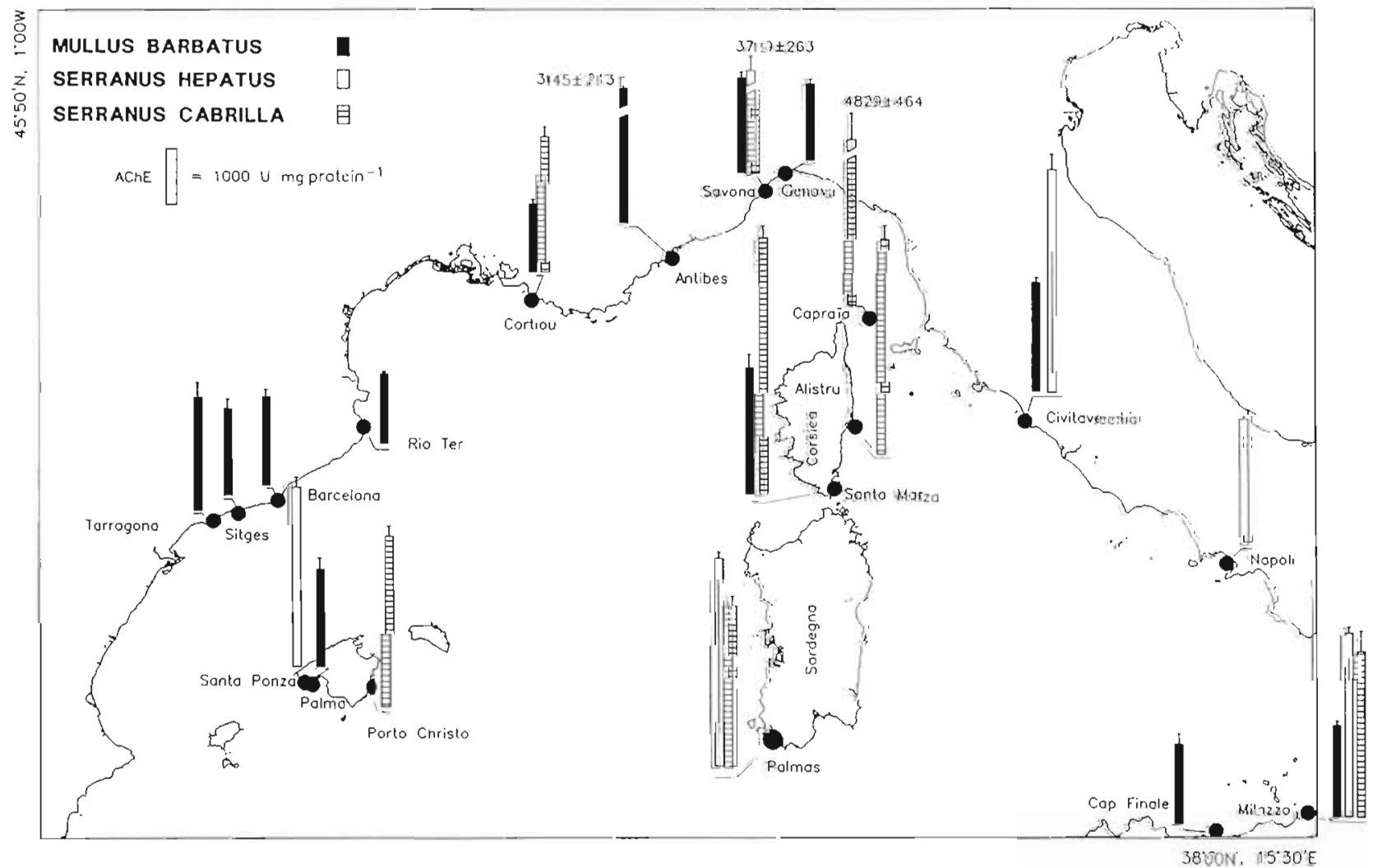

Fig. 2. Mullus barbatus, Serranus hepatus, S. cabrilla. AChE mhibition in muscle tissue. Mean and SD were calculated for 4 replicates per individual fished at the same station 


\section{Measurement of $\mathrm{AChE}$ activity}

The abundance of Mullus barbatus at 3 stations provided the opportunity to determine AChE activity in muscle tissue as a function of size. Measurements of AChE activity of 3 species at all stations are reported in Fig. 2. AChE activity in $M$. barbatus was found to be inversely proportional to size. Individuals measuring 160 to $180 \mathrm{~mm}$ fished at only 3 stations (Milazzo, Civitavecchia and Santa Manza) had very similar activities close to $1500 \mathrm{U} \mathrm{mg}$ protein ${ }^{-1}$ (1487 \pm $94,1495 \pm 77$ and $1450 \pm 67$ respectively), whereas younger individuals measuring 120 to $140 \mathrm{~mm}$ showed higher activities. These data are in agreement with observations concerning other species such as the dragonet Callionymus lyra and the comber Serranus cabrilla (G. Bocquéné unpubl.). Comparison of $\mathrm{AChE}$ activities in individuals measuring 120 to $140 \mathrm{~mm}$ showed that the highest values were found at Antibes (France), Santa Manza, Tarragona (Spain) and Civitavecchia; the lowest activities were found at Cortiou, Genoa (Italy), Cap Finale (Sicily), Rio Ter, Sitges and Barcelona (Table 2). The same measurements performed on $S$. cabrilla gave the lowest AChE values at Cortiou (2432 $\pm 181 \mathrm{U})$, and the highest at Santa Manza (4554 \pm 224) and Capraïa Island $(4829 \pm 464)$ northwest of Corsica. AChE activities measured in $S$. hepatus were lowest at Naples, Italy (2217 \pm 138 ) and highest at Civitavecchia $(3981 \pm 276)$. These figures, like the others, showed a difference in activity of as much as 50\% between extreme values, suggesting the presence of inhibitory substances in the biotope of fish sampled at the stations with the lowest activities

\section{Measurement of antioxidant and GST enzymes}

Some similarities were observable with catalase and GST measurement at 5 stations except for Mallorca (Table 3). Both activities tended to be significantly higher at Cortiou, the station close to the outlet of the Marseille waste treatment facility. Lower activity at Mallorca (reference site) was significant with catalase assays. Intermediate values were detected for catalase activity at the other stations GPX, however, showed a completely different profile, with the highest activities in the fish sampled at Mallorca and Cortiou. SOD and DT-diaphorase activities were similar at all stations, apart from Sitges and Tarragona, which showed the highest activities, respectively.

Table 2. Mullus barbatus, Serranus hepatus and S. cabrilla. AChE inhibition values ( $\mathrm{U}$ mg prot ${ }^{-1}$ ) in muscle tissue. Mean and SD were calculated for 4 replicates per individual fished at the same station. 8 individuals were analysed per station; nd: no data

\begin{tabular}{|lccc|}
\hline Station & Mullus barbatus & Serranus cabrilla & Serranus hepatus \\
\hline Alistru & nd & $3786 \pm 246$ & nd \\
Antibes & $3445 \pm 213$ & nd & nd \\
Barcelona & $1564 \pm 134$ & nd & nd \\
Cap Finale & $1427 \pm 195$ & nd & nd \\
Capraïa & $4829 \pm 464$ & nd & nd \\
Civitavecchia & $1934 \pm 87$ & nd & $3981 \pm 276$ \\
Cortiou & $1225 \pm 87$ & $2432 \pm 181$ & nd \\
Genoa & $1357 \pm 83$ & nd & nd \\
Milazzo & $1645 \pm 80$ & $2932 \pm 360$ & $3247 \pm 114$ \\
Naples & nd & nd & $2217 \pm 138$ \\
Palma & nd & $2851 \pm 1.65$ & $3705 \pm 116$ \\
Rio Ter & $1228 \pm 45$ & nd & nd \\
Santa Manza & $2250 \pm 241$ & $4554 \pm 224$ & nd \\
Santa Ponza & $1726 \pm 201$ & nd & $3220 \pm 185$ \\
Savona & $1698 \pm 105$ & $3719 \pm 263$ & nd \\
Sitges & $1538 \pm 169$ & nd & nd \\
Tarragona & $2012 \pm 266$ & nd & nd \\
\hline
\end{tabular}

Table 3. Activities of catalase ( $\mathrm{mol} \mathrm{min}^{-1} \mathrm{mg}$ prot $^{-1}$ ), glutathıone peroxidase (nmol min ${ }^{-1} \mathrm{mg}$ prot $^{-1}$ ), superoxide dismutase ( $\mathrm{U} \mathrm{min}^{-1} \mathrm{mg}$ prot ${ }^{-1}$ ), and glutathione S-transferase (nmol $\mathrm{min}^{-1} \mathrm{mg} \mathrm{prot}^{-1}$ ) in liver tissue of red mullet. NADPH- and NADHdependent DT-diaphorase activities (nmol $\left.\mathrm{min}^{-1} \mathrm{mg} \mathrm{prot}^{-1}\right)$ analysed in supernatant $(10000 \times \mathrm{g})$ of red mullet. Values are mean $\pm \mathrm{SD}(\mathrm{n}=6)$. 'Significant differences, with respect to Mallorca $(\mathrm{p}<0.05)$

\begin{tabular}{|c|c|c|c|c|c|c|}
\hline \multirow[t]{2}{*}{ Station } & \multirow[t]{2}{*}{ Catalase } & \multirow[t]{2}{*}{$\mathrm{SOD}$} & \multirow[t]{2}{*}{ GPX } & \multirow[t]{2}{*}{ GST } & \multicolumn{2}{|c|}{ DT-diaphorase } \\
\hline & & & & & NADH & NADPH \\
\hline Cortiou & $1819 \pm 197^{\circ}$ & $8.1 \pm 1.7$ & $111.2 \pm 11.5^{\circ}$ & $3063 \pm 143^{\circ}$ & $2.56 \pm 0.56^{\circ}$ & $1.13 \pm 0.19^{\circ}$ \\
\hline Barcelona & $1217 \pm 206^{\circ}$ & $8.2 \pm 1.6$ & $39.1 \pm 2.5^{\circ}$ & $1262 \pm 133$ & $2.68 \pm 0.46$ & $1.13 \pm 0.28$ \\
\hline Sitges & $1263 \pm 252^{\circ}$ & $14.4 \pm 2.0^{\circ}$ & $60.8 \pm 12.2^{\circ}$ & $1257 \pm 369$ & $3.17 \pm 0.33$ & $1.60 \pm 0.37$ \\
\hline Tarragona & $1389 \pm 122^{\circ}$ & $11.0 \pm 3.3$ & $47.0 \pm 5.6^{\circ}$ & $1435 \pm 131$ & $4.03 \pm 0.53$ & $2.18 \pm 0.19$ \\
\hline Mallorca & $704 \pm 62$ & $8.2 \pm 1.0$ & $147.8 \pm 12.6$ & $1603 \pm 112$ & $2.65 \pm 0.23$ & $1.39 \pm 0.12$ \\
\hline
\end{tabular}




\section{Measurement of DNA adducts}

$$
\text { PAH adducts (ELISA) }
$$

Immunochemical determination of PAH-DNA adducts was especially effective for specific contaminations. To test this genotoxic marker for monitoring purposes, measurements were performed in areas subjected to high but not specifically identified anthropogenic inputs. The polycyclonal serum used was produced by animals immunized with BPDE-I-DNA. This antibody does not recognize free BDPE molecules. The diol-epoxide guanine $\mathrm{N}_{2}$ adducts of PAH other than benzo[a]pyrene, such as chrysene and benz[a]anthracene $(\mathrm{BaP})$, possess a stereochemistry close to that of BPDE and are thus capable of being quantified with the BPDE-I-DNA antisera. For this reason, the method allows the assaying of the class of PAH diol-epoxide DNA adducts but data is expressed in BPDE-I-DNA equivalents

Adducts were measured at only 10 stations because of sampling constraints (Table 1). More than 10 diolepoxide PAH adducts per $10^{8}$ nucleotides were observed in red mullet DNA at Barcelona, Milazzo, Cap Finale, Ostia and Savona (Italy). In general, higher quantities of adducts were measured at Savona, Barcelona and Milazzo (Table 1), although the greatest amount was assayed at Cap Finale (20.8 adducts per $10^{8}$ nucleotides). EROD activity was highest near the oil refinery at Milazzo, which would appear to be a major source of PAH input (Fig. 1). Measurement of 12.8 adducts per $10^{8}$ nucleotides in red mullet livers at Savona was indicative of PAH exposure

No correlation was found between PAH adducts and EROD measurements in red mullet, confirming studies in trout (Masfaraud et al. 1992). However, quantities above 10 adducts per $10^{\circ}$ nucleotides were observed at stations with maximal EROD inductions (Barcelona, Ostia and Milazzo; Table 1). Although there were no direct correlations between adducts and EROD activities, the trend observed would indicate that organisms were exposed to complex mixtures of xenobiotics metabolized by enzymatic catalysis and accumulated in the form of PAH-DNA adducts.

\section{${ }^{32} \mathrm{P}$-postlabeling PAH adducts}

Adduct measurements in red mullet livers by the ${ }^{32} \mathrm{P}$ DNA postlabeling method allowed adduct profiles to be determined nonspecifically (Table 1). The postlabeling method showed the presence of 4 to 9 specific adducts per station and a total of 20 different adduct substances over all individuals (Fig 3). Four to 9 dis-

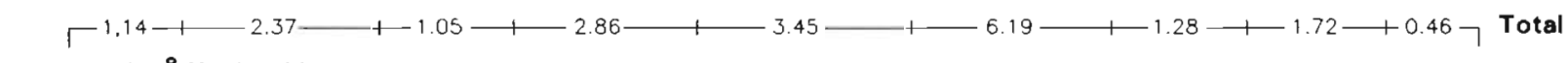

\section{Adducts $/ 10^{8}$ Nucleotides}

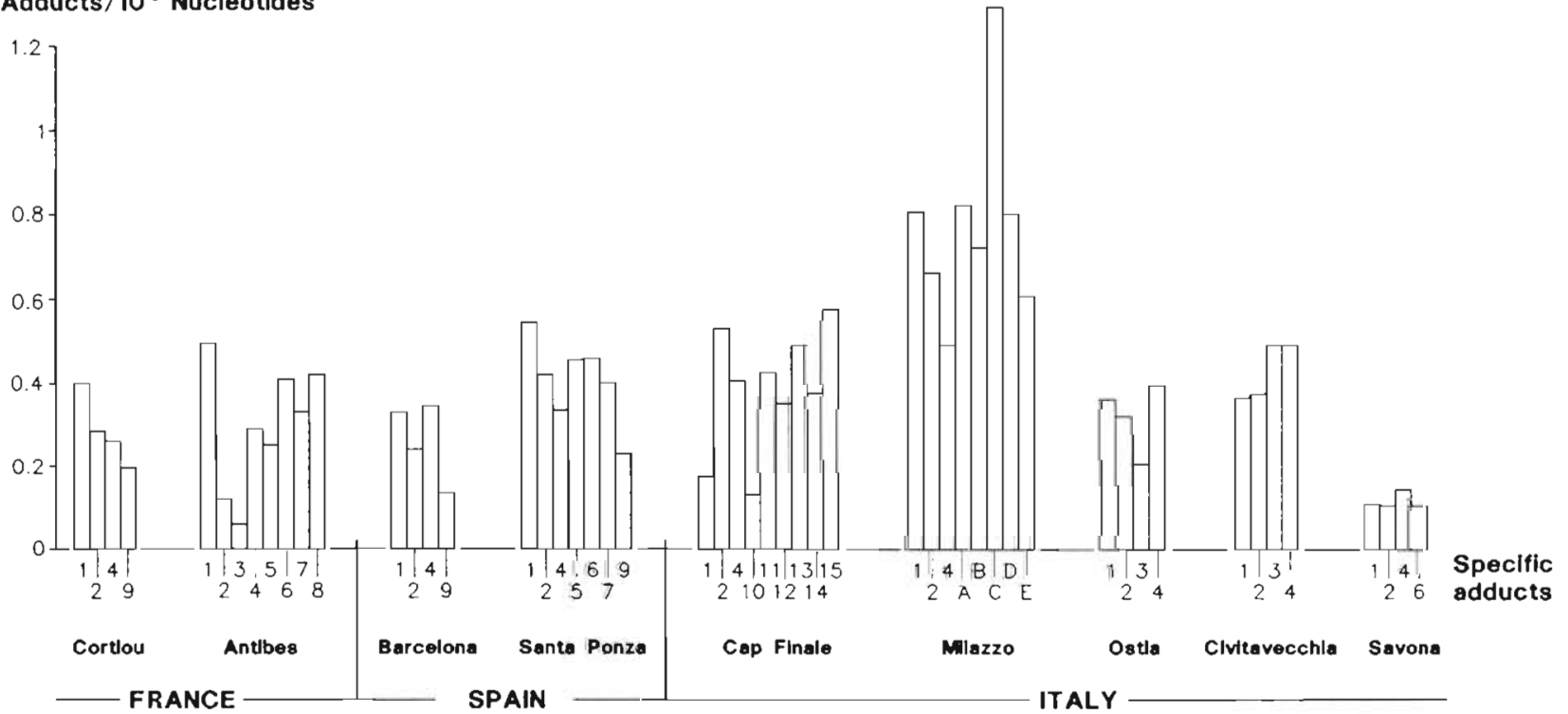

Fig. 3. Mullus barbatus. Profile of the different adducts measured by ${ }^{32} \mathrm{P}$-postlabeling technique in liver tissue at 9 of the 11 stations sampled (see Table 1). Apart from BPDE, designated by the number 1 as guanine $\mathrm{N}_{2}$ adducts, the other adducts were not identified. Their quantification is arbitrarily designated by numbers ranging from 1 to 15 . Adducts designated by letters have not been identified in freshwater fish, whereas numbers designate adducts common to freshwater fish (carp) and seafish. Letter and number designations correspond exclusively to the experiment of the laboratory in which the analysis was performed 
tinct adducts were also identified by this analytic method in the mullet Mugil auratus from the Adriatic Sea (Kurelec \& Gupta 1993) The Cap Finale (9 different adducts), Milazzo (8) and Antibes (8) stations had the richest adduct profiles, while 7 different adducts were identified at Santa Ponza. Similar profiles with 4 adducts were obtained at the Cortiou, Barcelona, Ostia and Civitavecchia stations. No adducts were found at Santa Manza and Genoa. The number of different adducts observed was not systematically indicative of a large quantity of total adducts. Nine different adducts and 3.5 adducts per $10^{8}$ nucleotides were identified at Cap Finale versus 8 and 6.2 adducts per $10^{8}$ nucleotides at Milazzo (Fig. 3). The Cortiou site, though directly influenced by domestic waste input, showed relatively few different adducts.

A very marked difference was noted between the minimum total adducts at Savona $\left(0.5\right.$ adducts per $10^{8}$ nucleotides) and the maximum at Milazzo (6.2 adducts per $10^{8}$ nucleotides). EROD activity and adduct measurements (ELISA and ${ }^{32} \mathrm{P}$ ), though not correlated, showed a common trend toward high values at Milazzo $_{i}$ a large quantity of $\mathrm{PAH}$ adducts was observed by using the 2 measurement techniques at Cap Finale. However, the results obtained at Savona for the 2 techniques showed different trends. Quantities above 10 adducts per $10^{8}$ nucleotides were noted with the diol-epoxide assay method (ELISA), whereas the lowest total adduct quantity was measured at Savona by the ${ }^{32} \mathrm{P}$ method (Table 1). The BPDE adduct, present in a majority of mammals and the only adduct identified by the postlabeling method in fish, was quantified at all sampling sites by the ${ }^{32} \mathrm{P}$ technique.

\section{Chemical measurements of PAHs in total sediment}

Preliminary analytic results of PAHs (Table 4) for a fraction of total sediment enabled us to classify the sampling stations into 3 categories (Fig. 4): those with total PAH of less than $200 \mathrm{ng} \mathrm{g}^{-1}$ (Santa Manza, Santa Ponza, Cap Finale, Milazzo and Antibes); those between 894.39 and $3058.46 \mathrm{ng} \mathrm{g}^{-1}$ (Barcelona and Savona); and those between 19371 and $37507.5 \mathrm{ng} \mathrm{g}^{-1}$ (Genoa \& Cortiou).

Surface sediments sampled near large cities at depths of 20 to $76 \mathrm{~m}$ allowed identification and quantification of PAH compounds of essentially pyrolytic origin.

Table 4. PAH distribution in total sediment $(<2 \mathrm{~mm})$. Concentrations are expressed in $\mathrm{ng} \mathrm{g}^{-1}$. Abbreviations for PAHs are explained in Fig. 5 legend

\begin{tabular}{|c|c|c|c|c|c|c|c|c|c|}
\hline & $\begin{array}{l}\text { Santa } \\
\text { Manza }\end{array}$ & $\begin{array}{l}\text { Santa } \\
\text { Ponza }\end{array}$ & $\begin{array}{l}\text { Cap } \\
\text { Finale }\end{array}$ & Milazzo & $\begin{array}{l}\text { Station } \\
\text { Antibes }\end{array}$ & Barcelona & Savona & Genoa & Cortiou \\
\hline DBT & 0.290 & 0.329 & 0.406 & 1.48 & 0.59 & 5.15 & 14.78 & 125.6 & 352.5 \\
\hline MBTs & 0.614 & 0.967 & 1.003 & 6.77 & 1.32 & 6.72 & 8.31 & 71.9 & 398.7 \\
\hline Phe & 3.555 & 2.239 & 3.214 & 9.04 & 6.26 & 74.81 & 245.53 & 2127.0 & 4047.6 \\
\hline MPs & 2.958 & 2.817 & 3.048 & 30.90 & 5.80 & 65.03 & 80.92 & 687.7 & 1515.7 \\
\hline DMPs & 2.939 & 4.278 & 3.215 & 42.65 & 5.03 & 51.54 & 37.02 & 370.6 & 906.1 \\
\hline An & 1.510 & 0.539 & 0.993 & 0.64 & 2.36 & 15.23 & 51.18 & 637.0 & 994.2 \\
\hline Fit & 7.726 & 3.060 & 7.272 & 9.62 & 20.30 & 119.19 & 506.67 & 3271.8 & 5141.0 \\
\hline Pyr & 7.138 & 2.814 & 6.421 & 1.1 .85 & 17.17 & 101.21 & 396.30 & 2309.0 & 4194.0 \\
\hline $\mathrm{BaA}$ & 7.676 & 2.654 & 4.845 & 3.73 & 12.10 & 53.50 & 214.75 & 1432.9 & 2758.5 \\
\hline Chr & 8.342 & 3.277 & 5.628 & 18.96 & 13.90 & 67.98 & 242.13 & 1508.0 & 3153.9 \\
\hline$B(j+b) F$ & 8.938 & 3.910 & 4.732 & 6.11 & 12.81 & 51.43 & 209.47 & 1345.6 & 2320.7 \\
\hline$B k F$ & 7.998 & 3.223 & 4.987 & 3.21 & 12.27 & 46.61 & 175.16 & 844.9 & 426.9 \\
\hline BeP & 6.013 & 2.655 & 4.068 & 11.54 & 10.14 & 47.91 & 168.94 & 879.7 & 1641.3 \\
\hline $\mathrm{BaP}$ & 8.628 & 3.541 & 5.172 & 3.81 & 12.53 & 49.39 & 205.96 & 1162.5 & 1780.9 \\
\hline Per & 2.279 & 0.994 & 1.982 & 2.09 & 3.60 & 20.29 & 55.97 & 283.8 & 481.8 \\
\hline $\operatorname{In} P$ & 6.157 & 3.212 & 4.619 & 3.33 & 10.57 & 33.30 & 129.02 & 634.1 & 1540.9 \\
\hline BghiP & 5.803 & 2.905 & 4.486 & 5.72 & 10.64 & 29.75 & 111.13 & 517.0 & 1531.3 \\
\hline dBahA. & 2.935 & 1.161 & 1.968 & 2.20 & 3.07 & 9.24 & 38.03 & 197.5 & 533.7 \\
\hline Total & 92 & 44.6 & 68.1 & 174 & 160 & 848 & 2891 & 18407 & 35209 \\
\hline MDBTs/DBT & 1.13 & 1.30 & 2.94 & 2.47 & 4.57 & 2.12 & 0.57 & 0.56 & 2.24 \\
\hline$(\mathrm{MPs}+\mathrm{DMPs}) / \mathrm{Phe}$ & 0.60 & 1.56 & 3.17 & 1.95 & 8.13 & 1.66 & 0.50 & 0.48 & 1.73 \\
\hline $\mathrm{BeP} / \mathrm{BaP}$ & 0.92 & 0.97 & 0.75 & 0.79 & 3.03 & 0.70 & 0.76 & 0.82 & 0.81 \\
\hline $\mathrm{Chr} / \mathrm{BaA}$ & 1.14 & 127 & 1.23 & 1.16 & 5.08 & 1.09 & 1.05 & 1.13 & 1.15 \\
\hline Bghip/InP & 0.99 & 0.89 & 0.90 & 0.97 & 1.71 & 0.94 & 0.82 & 0.86 & 1.01 \\
\hline Phe/An & 4.1 & 4.9 & 4.2 & 3.2 & 14.1 & 2.4 & 0.3 & 4.8 & 2.7 \\
\hline
\end{tabular}



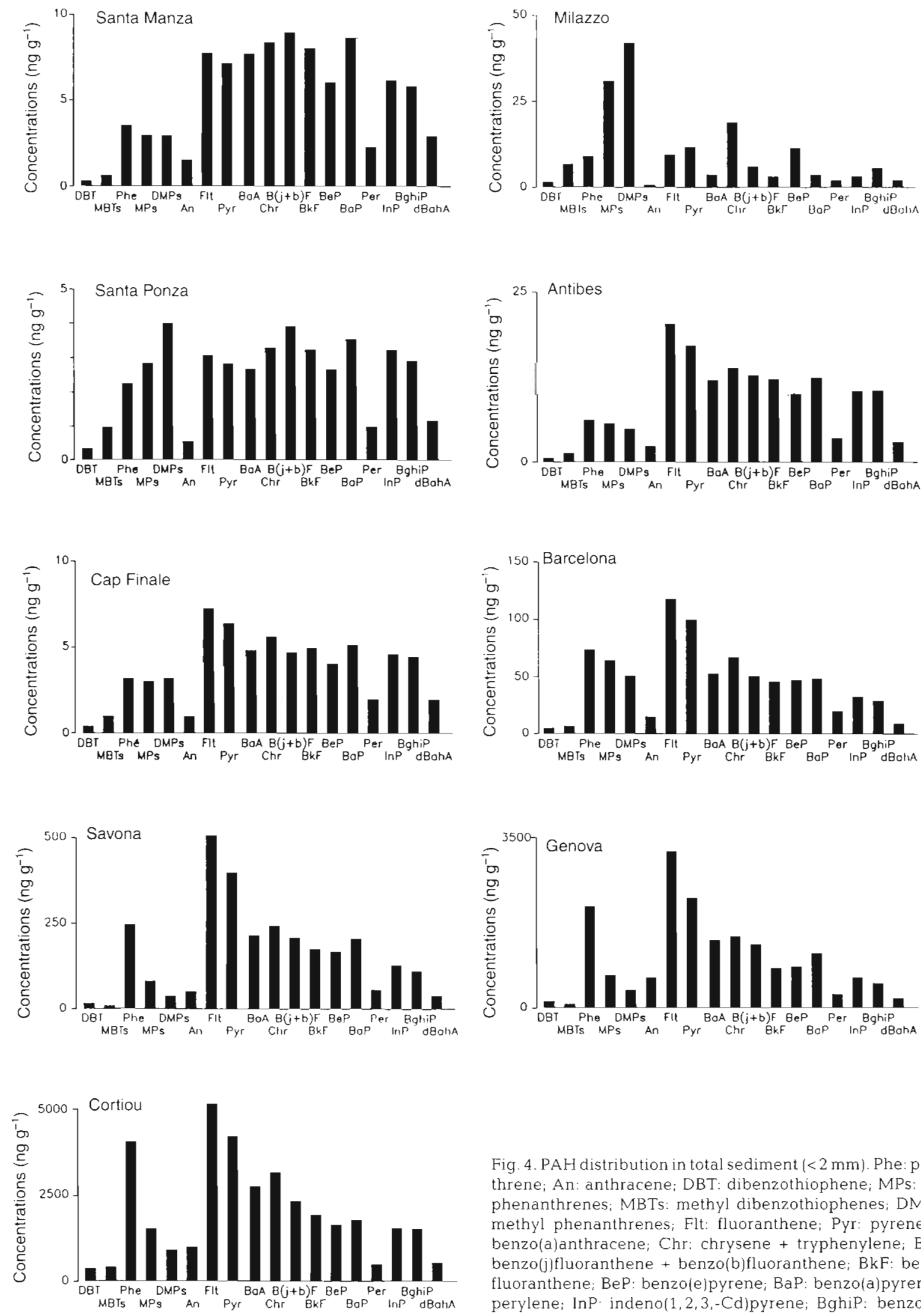

Fig. 4. PAH distribution in total sediment $(<2 \mathrm{~mm})$. Phe: phenanthrene; An: anthracene; DBT: dibenzothiophene; MPs; methyl phenanthrenes; MBTs: methyl dibenzothiophenes; DMPs: dimethyl phenanthrenes; Flt: fluoranthene; Pyr: pyrene; BaA benzo(a)anthracene; Chr: chrysene + tryphenylene; $\mathrm{B}(\mathrm{J}+\mathrm{b}) \mathrm{F}$ benzo(j)fluoranthene + benzo(b)fluoranthene; $\mathrm{BkF}$ : benzo(k)fluoranthene; BeP: benzolelpyrene; BaP: benzolalpyrene; Per perylene; InP indeno $(1,2,3,-$ Cd)pyrene; BghiP: benzo(g,h,i)perylene; dBahA: dibenzo-(a,h)anthracene 
This contamination is characteristic of the Mediterranean Sea (Raoux 1991, Raoux \& Garrigues 1993). Its major components (phenanthrene, fluoranthene and pyrene) are classical representatives of pollution of human origin (Figs. 4 \& 5). The lowest values of the structural isomers ratio (Chr/BaA; $\mathrm{BeP} / \mathrm{BaP}$ : BghiP/Inp
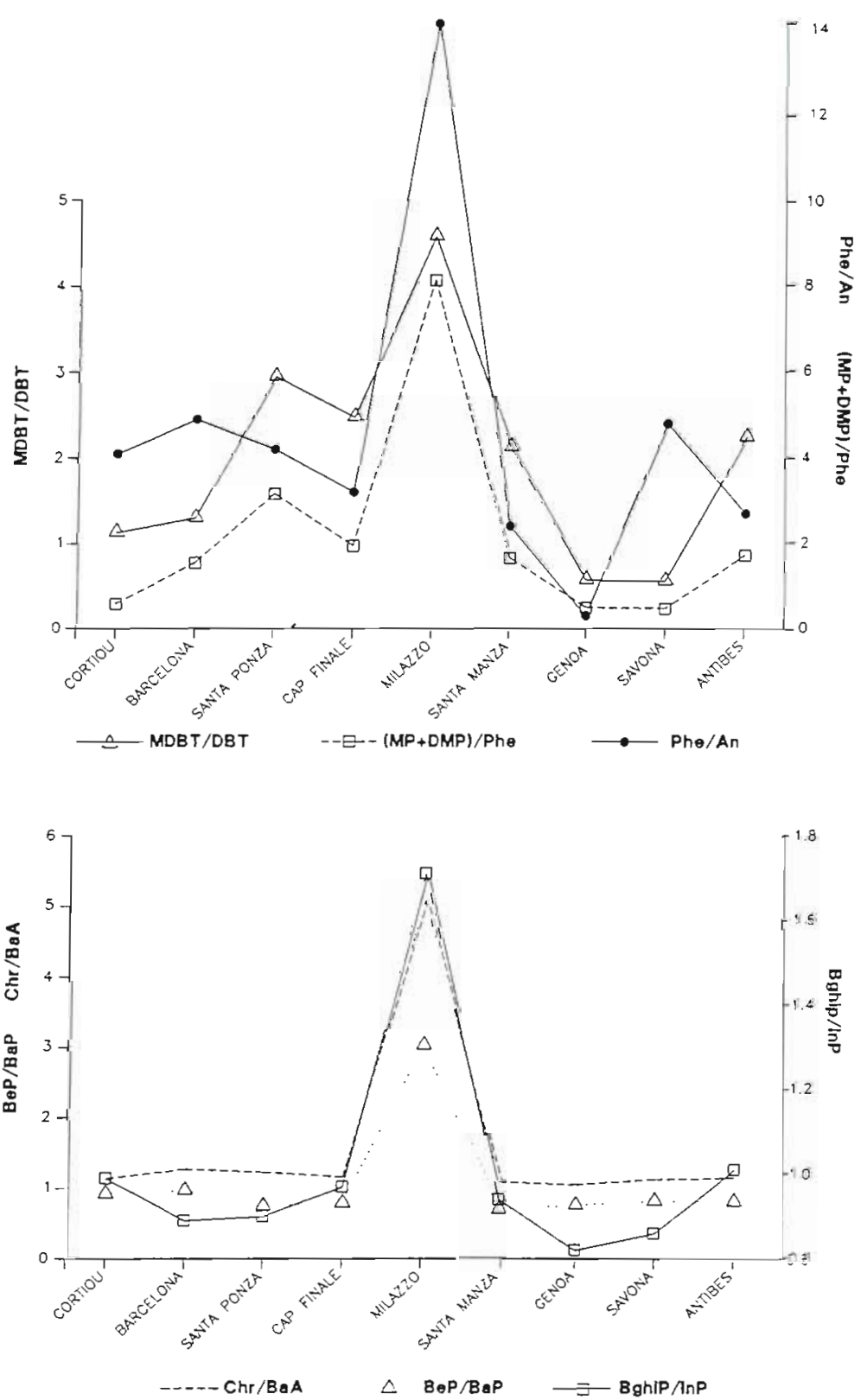

Fig. 5. Ratio of structural PAH isomers. Chemical measurement of PAH in surface sediment indicates the pyrolytic origin of this contaminant for all stations except Milazzo (petroleum origin). MDBT/DBT: methyl dibenzothiophene/dibenzothiophene; (MP+DMP)/Phe: (methyl phenanthrene + dimethyl phenantihrene)/phenanthrene; Phe/A.n: phenanthrene/anthracene; $\mathrm{Chr} / \mathrm{BaA}$ : chrysene/benzola)anthracene; $\mathrm{BeP} / \mathrm{BaP}$ : benzo(e)pyrene/benzo-

(a)pyrene: BghiP/InP: benzo(g,h,i)perylene/indeno $(1,2,3,-$ Cd $)$ pyrene and Phe/An; abbreviations defined in Fig. 4 legend) regularly used to identify petrogenic from pyrolitic origin (Sicre et al. 1987) showed that the sediment was contaminated by compounds with anthropogenic origins at the majority of the sampling stations. The highest values ratio was observed at Milazzo (Fig. 5)

The Milazzo station displayed a characteristic pattern of pollution due to petroleum, which presumably originated from the neighbouring oil refinery. In Milazzo methyl and dimethyl phenanthrene concentrations were more elevated than at the other stations (Table 3 ).

The ratios between alkylated and parent compounds for phenanthrene (MPs + DMPs)/Phe and dibenzothiophene MDBT/ DBT were elevated. They characterized the prevalence of alkylated compounds in the case of petrogenic contamination. The maximum ratio was observed at Milazzo. A peak with a low intensity was also observed at Santa Ponza with an alkylated compounds ratio, though it was not detectable with the other ratios studied (Fig. 5).

\section{DISCUSSION}

This scientific cruise was conducted in the vicinity of large and medium-sized cities of the northwestern part of the Mediterranean Sea which are impacted by industrial and domestic pollution. Pollutant evaluation of the marine environment was performed according to a multimarker approach. Three different categories of bioindicators have been developed to diagnose the biological and genotoxic effects of pollutants. EROD has been recommended for national and international biomonitoring programs and AChE and DNA adducts for local studies or those with a particular objective. The third category, antioxidant enzymes, includes biomarkers which require additional research before monitoring applications can be undertaken (ICES 1994).

These different indicators of exposure to xenobiotics were investigated in 3 target species of fish previously studied in the Mediterranean Sea (Mathieu 1990, Narbonne et al. 1991, Sanchez et al. 1993 , Burgeot et al. $1994 \mathrm{a}, \mathrm{b})$. The results show that these bioindicators gave different res- 
ponses according to site. EROD and AChE measurements allowed us to obtain information about the exposure state for each fish species (Figs. 1 \& 2). Observations obtained by the simultaneous use of these tests provided more consistent data, allowing a first evaluation to be made.

\section{EROD}

The EROD study focused on the red mullet Mullus barbatus because hepatic capacities of this species are better expressed by EROD variation than are those of the combers Serranus hepatus and S. cabrilla (Funari et al. 1987, Mathieu 1990). The highest inductions of EROD activity for combers were much lower than those for red mullets (Narbonne et al. 1991). The red mullet can also be trawl-fished, allowing more rapid and extensive sampling (Burgeot et al. 1994b). Inductions of EROD activity in red mullet at the Barcelona, Ostia and Milazzo stations were 2 to 3 times higher than those at other stations, indicating the presence of significant contaminant concentrations. Inductions of EROD activity at the Cortiou and Santa Manza stations were slightly lower but significant (Table 1). The distance from the source of pollution can influence the exposure level of fish, but it is very difficult to interpret this phenomenon on a large geographical scale. The geographical situation of the station is primarily set by trawl-fishing feasability and characteristics of the acean bottom. In order to more precisely interpret EROD variation in different areas in the future, this factor of variation must be more closely considered.

The 2 comber species, which have a different way of life than that of the red mullet, showed particularly high inductions at the Cortiou, Civitavecchia and Milazzo stations. Red mullet is more sensitive than comber to EROD activity, and induction is rapid. However, the activity is subject to seasonal variations (Mathieu 1990). EROD activity in males, in particular, is intensely expressed in May during the breeding period. During our study in April, we observed an increase in gonad maturation between the Cortiou station (sampled $10 \mathrm{~d}$ earlier) and the Cap Finale station. in conjunction with a $4^{\circ} \mathrm{C}$ increase in water temperature. As the sexual maturation factor influencing EROD activity can hinder interpretation of results, a multimarker approach is desirable to compensate for this type of problem. PAH measurements in sediment and DNA adduct measurements in liver tissue can provide complementary data on the origins and genotoxic impact of PAH. The identification of individual PAH in sediment can facilitate the determination of specific compounds responsible for biological effects.

\section{AChE}

Organophosphorus insecticides and carbamates are currently considered to be the most powerful cholinesterase inhibitors. Most of these substances induce significant inhibitions at concentrations in water of between 0.1 and $1 \mathrm{ng} \mathrm{l}^{-1}$. The presence of these substances in Cortiou station sediments was probably due to the proximity of the outlet for waste waters from the Marseille urban area (with 3.5 million inhabitants), although it is difficult to be certain in the absence of precise chemical data

In general, the highest values of AChE were measured in areas free of notable industrial or agricultural contamination (south Corsica, Capraila Island), whereas the lowest values were observed in highly contaminated sites (Gulf of Genoa, Cortiou, Naples, Barcelona). Data are scarce on the concentrations of organophosphorus and carbamate compounds in the different marine compartments. However, organophosphorus levels of up to $300 \mathrm{ng} \mathrm{g}^{-1}$ in fish tissue have been measured in the Ebro delta south of Barcelona (Barceló et al. 1990, UNEP/WHO 1991). Traces of ethylparathion and malathion have been detected in Camargue drainage water in France. Analytic problems make it difficult to obtain data on the presence of these substances in the marine environment because each substance must be identified individually. About 40 different organophosphorus compounds and about 20 distinct carbamates were used in France in 1993. Evaluation of organophosphorus and carbamate concentrations is thus extremely difficult, and the risk of underestimation is great. Moreover, a recent study (Bocquéné et al. 1995) confirmed the highly synergic effects of associated organophosphorus and carbamates. All this information on the sensitivity and specificity of the cholinesterase target and the synergy of inhibitory effects makes it likely, in the absence of chemical data, that there are inhibitory effects related to organophosphorus and carbamates in coastal marine sediment.

\section{Antioxidant and GST enzyme measurement}

Induction of antioxidant and GST enzymes were measured in Mullus barbatus liver tissue at 5 stations along the French and Spanish coasts to demonstrate alterations due to the presence of free radicals from pollutant metabolism (Table 3). Although relations between deaths or the existence of neoplasms and alterations in oxidative stress have not yet been clearly elucidated, inductions of antioxidant enzyme activities during exposure to PAHs and PCBs or even fungicide xenobiotics have been observed in flatfish (Chipman et 
al. 1992). However, overall responses are quite variable (Livingstone et al. 1992).

Catalase and GST were highest at the most contaminated area, which appeared to be a pollutant-related response, particularly for catalase. In contrast, GPX showed elevated activities at Cortiou (highly polluted) and surprisingly, at Mallorca (clean sea), indicating that factors other than pollution may influence this enzyme. Similar varying results were described by MatherMihaich \& DiGuilio (1991b), who reported a doserelated increase in catalase activity with no change in SOD or GPX in liver tissue of the catfish Ictalurus punctatus exposed to bleached kraft mill effluent.

No elevation of DT-diaphorases or SOD activity was evident at Cortiou. However, DT-diaphorase, NADHand NADPH-dependent, were maximal at Tarrgona and in areas where oil-related activities occur. In mammals, this enzyme appeared to be linked with cytochrome P450 IA1, but very little is known about this in fish. Moreover, the assay conditions may not be the best ones to measure its activity. The degree of inhibition by dicumarol of NADPH- or NADH-dependent DCPIP reductase activity in Mullus barbatus is generaly low and variable $(0.8$ to $16 \%)$ as reported by Livingstone et al. (1990) for Limanda limanda.

From these results, we conclude that the use of antioxidant enzymes alone as biomarkers of oxidative stress is far from sufficient (Peters et al. 1994). However, an integrated approach with sets of different biomarkers of exposure (e.g. EROD) or damage (e.g. DNA adducts), plus detailed chemical characterization of the sampling sites, would contribute to an evaluation of the biological effects of pollutants in the marine environment.

\section{PAH in sediment}

PAH measurements in sediment allowed us to define the origins of specific pollutants at each site. Two sources of oceanic PAH pollution are classically noted: natural continental sources and anthropogenic sources. The profiles obtained in the vicinity of large cities are characteristic of compounds of anthropogenic origin. In our study, the PAH contamination patterns in surface sediments were generally very similar, except at the Milazzo station, which had high levels of methyl and dimethyl phenanthrene (Fig. 4). These 2 compounds are fairly representative of petroleum-induced pollution, which appeared due to the presence of an oil refinery in that area. At the other stations, the major role of phenanthrene, fluoranthene and pyrene compounds was indicative of the pyrolytic contamination characteristic of areas of industrial and urban activity.
The expression of total PAH showed 3 contamination trends. Maximum contamination was registered at Cortiou (Table 4), a station situated several meters from the outlet for urban waste from Marseille. Concentrations for parent PAH currently analyzed were in the same range at the Barcelona, Savona, Genod and Cortiou stations as those in the Ebro delta in Spain (Albaigés et al. 1982) or in regions along the Spanish coast situated near urban areas (Albaigés et al. 1984). However, results at the Cortiou station were far higher than those measured between Marseille and the Rhône delta in southern France (Mille et al. 1981, 1982) or even those obtained within the Rhône delta (230 to $1720 \mathrm{ng} \mathrm{g}^{-1}$ ) (Milano et al. 1986). Nonetheless, interpretation of the distribution pattern for total PAH, considered as evidence for the identification of pollutant origin, is still difficult. All these results indicate the need for a more thorough study of the environmental geochemistry and specific activities at each site. However, these results show that the stations studied are subjected mainly to contamination of pyrolitic origin, except for Milazzo, which is subjected to characteristic inputs of petroleum products

\section{DNA adducts}

Measurements of DNA adducts by ${ }^{32} \mathrm{P}$-postlabeling enabled us to determine the presence of adducts without identifying them singularly (except BPDE-I-DNA) (Fig. 3). PAH diol epoxide-DNA adducts were the only adducts which could be identified by the immunochemical method.

The profiles of DNA adducts obtained allowed for differentiation of specific contamination features among sites probably subjected to human pollution sources, but also to different natural variables such as temperature, water depth and environmental oxygen pressure which can influence PAH transformation in the marine context. Assays of BPDE adducts by the ${ }^{32} \mathrm{P}$ method showed that BPDE was present at all stations, but at varying concentrations (Fig. 3). Quantification of BPDEI-DNA equivalents by ELISA allowed us to observe wide variations between the different sites (Table 1).

The complementary data obtained by the 2 methods are useful for evaluating the genotoxic effect of PAH. PAH-DNA measurements, currently used in human monitoring as an indicator of pollution (Poirier et al. 1980), have been compared with the ${ }^{32} \mathrm{P}$-postlabeling method performed on humans (Schoket et al. 1993). Like our results for fish, this comparison exercise on humans allowed us to observe the lowest values with the ${ }^{32}$ P-postlabeling method in spite of a larger measurement adduct spectrum than that of the ELISA method. The discordance observed between the 
2 methods could be due to the DNA extraction method used. An insufficient selective DNA extraction with the ELISA method could induce the detection of RNA adducts and an overevaluation of DNA adducts. A cross reaction with PAHs possessing the same stereochemistry as BaP could be quantified by ELISA and not by ${ }^{32} \mathrm{P}$-postlabeling because of their small size. Lastly, loss of adducts could be improved during the enrichment phase with P1 nuclease. P1 nuclease could involve an $80 \%$ loss of adducts on the $\mathrm{C}_{3}$ of the guanine (A. Pfhol-Leszkowicz unpubl.).

However, further studies using the 2 measurement methods ( ${ }^{32} \mathrm{P}$-postlabeling and the immunochemical assay) in relation with PAH chemical measurements in sediment should be performed to facilitate the interpretation of results, a process which is often difficult and related to seasonal variations (Kurelec \& Gupta 1993). The use of markers such as BPDE-I-DNA equivalents indicates that the exposure of fish to complex PAH mixtures results from superimpositions of emissions from several sources (Lipiatou 1989). For example, large quantities of PAH-DNA adducts were recorded at the Milazzo site with both methods. The high EROD activity measured at this same site suggests that fish living there are exposed to heavy pollution and to bioactive chemical substances. The Cap Finale site, which had a very rich DNA adduct profile with the ${ }^{32} \mathrm{P}$ method, also showed high amounts of PAH-DNA with the ELISA method. Although PAHs represent only a small fraction of the complex mixtures of petroleum hydrocarbons in the environment, these results suggest that adduct measurements are more particularly effective at sites highly contaminated by PAH (Dunn et al. 1987, Stein et al. 1992). These studies confirm other in vivo experiments (Maccubin 1994) which support the contention that the sediment is a possible source for at least some of the genotoxic chemicals to which the fish are exposed. But the ultimate use of the 2 DNA adduct assay methods for monitoring purposes require further studies to evaluate their interest for the monitoring of the marine environment.

In the perspective of genotoxic studies, the monitoring of DNA adducts in fish livers could provide an interesting tool for observing genetic alterations related to long-term exposure. The poor capacities for repair of DNA alterations in fish (Dunn et al. 1987) indicate that data are required concerning the different exposure possibilities. The formation of DNA adducts is a key phase in the onset of cancer, providing a link between genetic mutations in fish livers and the genotoxic effect of chemical substances in the marine environment. Even though adducts have been included among the useful exposure biomarkers for the monitoring of the aquatic environment, certain factors are capable of introducing confusion. The for- mation of adducts in unpolluted areas, seasonal variations in their formation (Kurelec \& Gupta 1993) and the mechanisms of DNA repair dependent on exposure time need to be considered before any attempts are made to interpret carcinogenic effects in environmental monitoring. Another difficulty in field study is the route and the duration of exposure of wild fish to a complex mixture of pollutants. In spite of this difficulty, the concordance of data observed at the Milazzo site, which showed very strong enzymatic EROD activity as well as a high amount of DNA adducts in Mullus barbatus liver tissue, indicates the sensitivity of these biomarkers to the sediment contaminated by petroleum products

In conclusion, the results obtained here suggest that the complementary use of several indicators of biological and genotoxic pollution facilitates evaluation of the state of exposure of these organisms to complex mixtures of chemical pollutants. Mullus barbatus were proven suitable for bioindicator analysis. Exposure to insecticides or hydrocarbons were identifiable at the most contaminated sites by using enzymatic bioindicators (EROD and $\mathrm{AChE}$ ). The identification of individual PAHs in sediment can facilitate the determination of specific compounds responsible for biological effects For this initial field study, the choice of areas in the northwestern Mediterranean Sea near large cities provided a preliminary estimation of genotoxic alterations revealed by DNA adduct assays. The application of parameters recommended by the international community (ICES and MED-POL) to sensitive sites, the use of a multimarker approach and the assaying of $\mathrm{PAH}$ in sediment provided experience and data which will be beneficial to the future use of certain bioindicators for long-term monitoring.

With respect to field studies, more work is needed in identifying the adducts observed in wild fish, especially for the complex pattern observed by using ${ }^{32} \mathrm{P}$ postlabeling In order to complete the multimarkers approach, it would be interesting to estimate tumors and neoplasia in wild fish combined with the evaluation of critical genetic targets of DNA adducts such as tumors, suppressor genes and oncogenes.

Acknowledgements. We thank Dr Tie Lang Young from Columbia University, USA for his participation in DNA adduct measurements. We are grateful for L. Giboire's assistance with the figures and to $\mathrm{M}$. J. Thébaud for secretarial assistance.

\section{LITERATURE CITED}

Albaigés J, Algaba J, Bayona JM, Grimalt J (1982) New perspectives in the evaluation of anthropogenic inputs of hydrocarbons in the western Mediterranean coast. Vieme journées d'études des pollutions, Cannes, Commission Internationale pour l'Exploration. Scientifique de la Mer 
Albaigés J, Grimalt J, Bayona JM, Risebrough R, De Lappe B Walker W (1984) Dissolved, particulate and sedimentary hydrocarbons in a deltalc environment. Org Geochem 6 $237-248$

Baird WM (1979) The use of radioactive carcinogens to detect DNA modifications. In: Grover PL (ed) Chemical carcinogens and DNA 59. CRC, Boca Raton, FL, p 89-112

Barceló D, Porte C, Cid J, Albaigès J (1990) Determination of organophosphorus compounds in coastal environments by gas chromatography nitrogen phosphorus and main spec. trometric detection. Int $J$ environ analyt Chem 38:199-209

Benson AM, Hunkler MJ, Talalay P (1980) Increase of NAD(P)H: quinone reductase by dietary antioxidants. Possible role in protection against carcinogenesis and toxicity Proc nat Acad Sc USA 77:5216-5220

Bocquéné G (1995) L'acetylcholinestérase, marqueur de neurotoxicité. Application à la surveillance des effets biologiques des polluants chez les organismes marins. Thèse de doctorat en océanographie, Ecole Pratique des Hautes Etudes, Paris

Bocquéné G, Bellanger C, Cadiou Y, Galgani F (1994) Joint action of combinations of pollutants on the acetylcholinesterase activity of several marine species. Ecotoxicology $4: 266-279$

Bradford M (1976) A rapid method quantification of protein utilising the principle dry binding. Analyt Biochem 72 $248-264$

Burgeot T (1994) L'ethoxyresorufine-o-deethylase, les adduits à l'ADN et les micronuclei dans les organismes marins. Application à la surveillance des effets biologiques sur les côtes Françaises. Thèse de doctorat, Université de Nantes, p $101-123$

Burgeot $T$, Bocquéné $G$, Pingray $G$, Godeffroy $D$, Legrand $J$, Dimeet J, Marco F, Vincent F, Henocque Y, Oger Jeanneret H, Galgan F (1994a) Monitoring biological effects of contamination in marine fish along French coasts by measurement of ethoxyresorufin-O-deethylase activity. Ecotoxicol environ Saf $4: 131-147$

Burgeot $T$, Bocquéné $G$, Truquet $P$, Le Dean L, Galgani $F$ (1994b) Induction of EROD activity in red mullet (Mullus barbatus) along the French mediterranean coasts. Sci total Environ 142:213-220

Burke MD, Mayer RT (1974) Ethoxyresorufin: direct fluor1metric assay of microsomal O-dealkylation which is preferentially inducible by $\beta$-methylcholanthrene. Drug Metab Disposis 2:583-588

Chipman JK, Marsh JW, Livingstone DR, Evans B (1992) Genetic toxicity in dab Limanda limanda from the North Sea. Mar Ecol Prog Ser 91:121-126

Dawe CJ, Stanton MF, Schwartz FJ (1964) Hepatic neoplasms in native bottom-feeding fish of Deep Creek Lake, Maryland. Cancer Res 24:1194

DiGiuljo RT, Washburn PC, Wennig RJ, Jewel GW (1989) Biochemical responses in aquatic animals: a review of determinants of oxldative stress. Environ Toxicol Chem 8 : $1103-11.23$

Dunn BP, Balck JJ, Maccubbin A (1987) ${ }^{32}$ P-postlabeling analysis of aromatic DNA adducts in fish from polluted water. Cancer Res 47:6543-6548

Ellman GL, Courtney KO, Andres V, Featherstone RM (1961) A new and rapid colorimetric determination of acetylcholinesterase activity. Biochem Pharmacol 7 $88-95$

Ericson G, Liewenborg B, Balk L (1995) Comparative ${ }^{32} \mathrm{P}$ postlabeling analysis of DNA adducts in perch (Perca fluviatilis) from unpolluted polluted areas in Swedish coastal water. Mar environ Res 39:303-307
Förlin L, Andersson T (1985) Storage conditions of rainbow trout liver cytochrome P450 and conjugating enzymes. Comp Biochem Physiol 80B:569-572

Funari E, Zoppini A, Verdina A, De Angelis G, Vitozi L (1987) Xenbiotic-metabolizing enzyme systems in test fish: I. Comparative studies of liver microsomal. monooxygenases. Ecotoxicol environ Saf 13:24-31

Galgani F, Bocquéné G (1989) Utilisation des lecteurs de microplaques pour les mesures colorimétriques et enzymatiques. Océanis 15:443-441

Galgani F, Payne J (1991) Biological effects of contamunants: microplate method for measurement of ethoxyresorufin-odeethylase (EROD) in fish. Technique in marine environmental sciences. Int Counc Explor Sea, Copenhagen

GICBEM (groupe interface chimie biologie écosystèmes marins) (1992) Activités des systèmes de bioprotection d'organismes marins représentatifs d'écosystèmes benthiques côtiers. Rapport final à la commission des communautés européennes (DG XII-B-2). Faculté de Nice, contrat de recherche EV 4V 0163-F (EDB)

Greenwald RA. (1985) Handbook of methods for oxygen radical research. CRC Press, Boca Raton, FL

Grzebyk D. Galgani F (1991) Measurement of organic pollution in marine organisms. Rapid determination of EROD induction using plate readers. Aquat Living Res 4:53-59

Habig WH, Pabst MJ, Jakoby WB (1974) Glutathione S-transferase. J biol Chem 25:7130-7139

ICES (International Council for the Exploration of the Sea) (1994) Report of the working group on the biological effects of contaminants. CM 1994/ENV: 3 Rel. general secretary, Pleagade 2-4,1261, Copenhagen

Kurelec B. Gupta RC (1993) Biomonitoring of aquatic systems. In: Phillips DH, Castegnaro $M$, Bartsch $\mathrm{H}$ (eds) Postlabelling methods for detection of DNA adducts. International Agency for Research on Cancer, Lyon, p 365-372

Lipiatou E (1989) Contribution à l'étude géochimique des hydrocarbures aliphatiques et aromatiques dans le delta du Rhône et le golfe du Lion. Thèse de doctorat, Université de Paris 6

Lipiatou E, Saliot A (1992) Biogenic aromatic hydrocarbon geochemistry in the Rhone River delta in surface sediments from the open northwestern Mediterranean Sea. Estuar coast Shelf Sci 34:515-531

Livingstone DR, Archibald S, Chipman KL, Marsh JW (1992) Antioxidant enzymes in liver of dab Limanda limanda from the North Sea. Mar Ecol Prog Ser 91:97-104

Livingstone DR, Garcia-Martinez P, Michel X, Narbonne JF, O'Hara S, Ribera D, Winston GW (1990) Oxyradical generation as pollution-mediated mechanism of toxicity in the common mussel, Mytilus edulis L., and other molluscs. Funct Ecol 4:415-424

Lowry OH, Rosebrough NJ, Farr AL, Randall RJ (1951) Protein measurement with Folin phenol reagent. $J$ biol Chem 193:265-275

Maccubin AE (1994) DNA adduct analysis in fish: laboratory and field studies. In: Molecular, biochemical, and cellular perspectives. Aquat Toxicol, CRC Press, Boca Raton, FL. p $267-294$

Markovics B, Witas H, Gabrielak I, Szabo L (1987) Paraquat as an agent affecting antioxidant enzymes of common carp erythrocytes. Comp Biochem Physiol 87C:217-219

Maslaraud JF, Pfhol-Leszkowicz A, Malaveille C, Keith G. Monod G (1992) 7-Ethoxyresorufin-O-deethylase activity and level of DNA adducts in trout treated with benzo(a)pyrene. Mar environ Res 34:351-354

Mather-Mihaich E. DiGiulio RT (1986) Antioxidant enzyme activities and malonaldehyde, glutathione and methemo- 
globin concentrations in channel catfish exposed to DEF and $\mathrm{N}$-butylmercaptan. Comp Biochem Physiol 85C:427-432

Mather-Mihaich E, DiGiulio RT (1991a) Antioxidant, mixedfunction oxidase and peroxisomal responses in channel catfish exposed to DEF and $\mathrm{N}$-butyl mercaptan. Comp Biochem Physiol 85C:427-432

Mather-Mihaich E, DiGiulıo RT (1991b) Oxidant, mixed-function oxidase and peroxisomal responses in channel catfish exposed to a bleached kraft mill effluent. Archs environ Contam Toxicol 20:391-397

Mathleu A (1990) Varlations des activités de biotransformation chez les porssons marins application à la surveillance biologique de l'environnement. Thèse universitaire, [ $\mathrm{nl}$ versité d'Alx-Marseille

McCarthy JF, Jacobson DN, Shugart Lee R, Jimenez BD (1989) Pre-exposure to 3-methylcholantrene increase benzo(a)pyrene adducts on DNA of bluegill sunfish. Mar environ Res 28:323-328

McCord JM, Fridovich OJ (1969) Superoxide dismutase: an enzymatic function for erythrocuprein (hemocuprein). $\mathrm{J}$ biol Chem 244:6049-6055

Milano JC, Fache B, Vernet JL (1986) Pollution par les hydrocarbures polyaromatiques du sédiment, de la flore et de la faune du site du cap Sicié à la sortie de l'émissaire de la ville de Toulon (côte méditerranéenne française). J Rech Océanogr 11:13-96

Mille G, Chen JY, Dou HJM (1982) Polycyclic aromatic hydrocarbons in Mediterranean coastal sediments. Int $\mathrm{J}$ envıron analyt Chem 11:295-304

Mille G, Dou H, Christianı G, Giusti G (1981) Hz drocarbures présents dans les sédiments còtiers superficinls méditerranéens I: étude qualitative et quantitative fine. Environ Pollut Ser B Chem Phys 2:437-450

Narbonne JF, Ribera D, Michel X, Raoux C, Garrigues P. Monod JL (1991) Indicateurs biochimiques de contamination de l'environnement marin: etude comparative en mer Méditerranée. Océanis 17:257-275

Peters LD, Porte C, Albaigés J, Livingstone DR (1994) 7 Ethoxyresorufin-O-deethylase (EROD) and antioxidant enzyme activities in larvae of sardine (Sardina pilchardus) from the north coast of Spain. Mar Pollut Bull 5:299-304

Pfhol-Leszkowicz A, Chakor K, Creppy EE, Dirheimer G (1991) DNA-adduct formation in mice treated with ochratoxin A. In: Castegnaro M, Plestina R, Dirheimer $\mathrm{G}_{\text {, Cher- }}$ nozemsky IV. Bartsch $H$ (eds) Mycotoxin, endemic nephropathy and urinary tract tumours. IARC Scientific publications No 115, International Agency for Research on Cancer, Lyon, p 245-253

Pfhol-Leszkowicz A, Grosse Y, Kane A, Creppy EE, Dirheimer G (1993) Differential DNA adduct formation and disappearance in three mice tissues after treatment by mycotoxin, ochratoxin A. Mutat Res 289:265-273

Poirier MC, Santella R, Welnstein IB, Grunberg D, Yuspa SH (1980) Quantification of benzo (a) pyrene-deoxyguanosine adducts by radioimmunoassay. Cancer Res 40:412-416

Raoux C (1991) Modélisation du mécanisme de contamination par les hydrocarbures aromatiques polycycliques (HAP) des sédiments marins côtiers de méditerranée: conséquences sur la biodisponibilité des HAP dans le milieu marin. Thèse de doctorat, Université de Bordeaux

Raoux C, Garrigues P (1993) Mechanısm model of polycyclic aromatic hydrocarbon contamination of marine coastal sediment from Mediterranean Sea. In: Garrigues P, Lamotte A (eds) Polycyclic aromatic compounds: synthesis, properties, analytical measurements, occurrence and biological effects. Gordon and Breach Science Publıshers, Bordeaux, p 443-450

Reddy MV, Randerath K (1986) Nuclease P1 medrated enhancement of sensitivity of ${ }^{32} \mathrm{P}$-postlabelung test for structurally diverse DNA-adducts. Carcinogenesis 7: $1543-1551$

Roméo A, Viarengo A, Lafaurie M (1993) Starting of a biomonitoring programme in the PACA (Provence-AlpesCôte d'Azur)-Liguria area. Séminaire européen sur les technologies marines et environnement de meditérranée 4-6 mars 1993. S Margherita Ligure, Commission de la Communauté Europécnne, DG XII, Ministère Italien des affaires étrangères, p 111-113

Sanchez J, Solé M. Albaigés J (1993) A comparison of distributions of PCB congeners and other chlorinated compounds in fishes from coastal areas and remote lakes. Int $J$ environ analyt Chem 50:269-284

Santella RM, Grinberg-Funes RA, Young CD, Singh VN Wang LW, Perera FP (1992) Cigarette smoking related polycyclic aromatic hydrocarbon-DNA adducts in peripheral mononuclear cells. Carcinogenesis 13 2041-2045

Schoket B, Phillips DH, Poirier CM, Vincze I (1993) DNA adducts in peripheral blood lymphocytes from aluminum production plant workers determined by ${ }^{32}$ P-postlabeling and enzyme-linked immunosorbent assay. Environ Health Perspect 99:307-309

Sicre MA, Marty JC, Saliot A, Aparicio X. Grimalt J, Albaigés $\mathrm{J}$ (1987) Aliphatic and aromatic hydrocarbons in different sized aerosols over the Mediterranean Sea: occurrence and ongin. Atmos Environ 21:2247-2259

Sikka HC, Steward AR, Kandaswami C, Rutkowski JP, Kumar S, Zaleski J, Early K, Gupta RC (1991) Metabolism of benzo(a)pyrene and persistence of DNA adducts in the brown bullhead (Ictalurus nebulosus). Comp Biochem Physiol 100C:25

Stein JE, Collier TK, Reichert WL, Castillas E, Hom T, Varanasi U (1992) Bioindicators of contaminant exposure and sublethal effects: studies with benthic fish in Puget Sound, Washington. Environ Toxicol Chem 11: $701-714$

Stein JE, Reichert WL, French B, Varanasi U (1993) ${ }^{32}$ P-postlabeling analysis of DNA adduct formation and persistence in English sole (Pleuronectes vetulus) exposed to benzola]pyrene and $7 \mathrm{H}$-dibenzo[c,g]carbazole. ChemicoBiol Interactions 88:55-69

UNEP/WHO (1991) Biogeochemical cycles of specific pollutants (activity $\mathrm{K}$ ): final report on project on survival of pathologenic organisms in seawater. MAP technical report series, No 55, United Nations Environment Programme, Athens, p 118-147

Varanasi U, Nishimoto M, Reichert WL, Ederbart B (1987) Comparative metabolism of benzo(a)pyrene and covalent binding to hepatic DNA in English sole. Starry flounder, and rat. Cancer Res 46:3817-3824

Varanası U, Reichert WL, Stein JE (1989) ${ }^{32}$ P-postlabeling analysis of DNA adducts in liver of wild Iinglish sole (Parophrys vetulus) and winter flounder (Pseudopleuronectes americanus). Cancer Res 49:1171 1177

Manuscript first recenved: March 14, 1995

Revised version accepted: June 28, 1995 